\title{
Role of Temperature and Gibberellic Acid in Stimulating Embryo Elongation and Radicle Emergence of Hepatica asiatica Nakai Seeds
}

\author{
Young Shin Chon $^{1}$, Kyeong Jin Jeong ${ }^{2}$, Sang Woo Lee ${ }^{1}$, and Jae Gill Yun ${ }^{1 *}$ \\ ${ }^{1}$ Department of Horticultural Science, Gyeongnam National University of Science and Technology, Jinju 660-758, Korea \\ ${ }^{2}$ Graduate School, Gyeongnam National University of Science and Technology, Jinju 660-758, Korea
}

\begin{abstract}
This research was performed to determine the temperature requirements for embryo growth and radicle emergence of Hepatica asiatica Nakai, a perennial herb native to Korea. Seed viability, embryo growth, and radicle emergence were monitored in seeds exposed to various temperatures $\left(10,15,20^{\circ} \mathrm{C}\right.$ and $\left.30 \rightarrow 15^{\circ} \mathrm{C}\right)$. Laboratory experiments at various temperatures revealed that (1) embryo elongation occurred effectively between 10 and $15^{\circ} \mathrm{C}$; (2) radicle emergence occurred only at $15^{\circ} \mathrm{C}$; (3) a warm stratification (2-8 weeks at $30^{\circ} \mathrm{C}$ ) was not required for embryo elongation and radicle emergence, and led to inhibition of radicle emergence; (4) application of gibberellic acid $\left(\mathrm{GA}_{3}\right)$ promoted embryo growth, but not radicle emergence. These results suggested that $H$. asiatica seeds have two separate mechanisms to overcome dormancy, either by $\mathrm{GA}_{3}$ (morphological dormancy) or temperature (physiological dormancy), and warm stratification is not involved in breaking radicle dormancy. These findings indicate that H. asiatica seeds have morphophysiological dormancy.
\end{abstract}

Additional key words: morphophysiological dormancy, native plant, plant hormone, Ranunculaceae

\section{Introduction}

Hepatica is a genus of herbaceous perennials in the Ranunculaceae and is native to central and northern Europe, Asia and eastern North America. It can be found in deeply shaded deciduous woodland and scrubland. It has been known that seeds are dispersed from this plant in spring and show radicle emergence in autumn (October in South Korea), but cotyledons do not emerge until early spring of next year. The color of flowers varies from dark blue to pure white bloom from late winter to following early spring, followed by leaf development. Some leaves wither away during summer and the rest remain in evergreen until the following spring (Tamura, 1993).

Hepatica nobilis occurs in eastern North America, Europe, and Japan, and Hepatica nobilis Schreber var. japonica Nakai is native to Japan (Hara and Kurosawa, 1958), where it is called 'Yukiwariso'. In Japan, H. nobilis flowers have double petals and various colour patterns, which have been developed by breeding with wild varieties. $H$. asiatica Nakai was considered as a variety of $H$. nobilis (Hara, 1952), but now considered as a separate species (Nakai, 1937). H. asiatica Nakai is a perennial plant native to Korea and called 'No-ru-gui' in Korean (Lee, 1982). H. asiatica inhabits areas with deciduous trees and herbaceous plants where soils are somewhat acidic (pH 5.1-5.3). Monthly average of air temperature in these natural habitats ranged between -5 and $5^{\circ} \mathrm{C}$ in winter, 18 and $24^{\circ} \mathrm{C}$ in summer, and 10 and $15^{\circ} \mathrm{C}$ in spring and autumn (Lim and Sang, 1990).

H. asiatica has been studied in terms of methyl alcoholextractable phytochemical components (Chi and Lee, 1981), growth and cultivation (Lim and Sang, 1990), taxonomic status and genetic variation (Kim and Lee, 1994), life cycle (Hong, 1995), differentiation and development of flower buds (Lee et al., 2005; Song et al., 2003), and control of flowering (Lim et al., 2007; Song et al., 2003).

\footnotetext{
*Corresponding author: jgyun@gntech.ac.kr

※ Received 25 September 2014; Revised 16 January 2015; Accepted 29 January 2015. This work is supported by a grant (109096-05-3-HD120) from the Ministry for Food, Agriculture, Forestry and Fisheries (MIFAFF).

(C) 2015 Korean Society for Horticultural Science
} 
However, information on seed germination are needed for mass propagation and maintenance of population for this species, which has not been reported before, except for other Hepatica species. Fresh seeds of H. nobilis Schreber (Engell, 1995) and H. nobilis Schreber var. japonica (Nomizu et al., 2004) were found to contain underdeveloped embryos. Seeds of H. americana and H. acutiloba exhibited deep morphophysiological dormancy. Seeds of $H$. acutiloba were also reported to have epicotyl dormancy and radicle emergence occurs in autumn at low temperatures following a period of high temperatures in summer, while cotyledons emerge in spring after a period of low temperatures during winter (Baskin and Baskin, 1985).

The objective of this study was to assess temperature requirements and the role of exogenous $\mathrm{GA}_{3}$ on embryo growth and radicle emergence of $H$. asiatica seeds under controlled conditions, i.e., in the laboratory and inside a non-heated plastic house to characterize seed dormancy and promote seed germination of this species.

\section{Materials and Methods}

\section{Seeds collection}

Seeds of $H$. asiatica were collected in May 2010 and June 2011 just before dispersion from parent plants. Plants were grown in a non-heated plastic house on the campus of Gyeongnam National University of Science and Technology, Jinju $\left(35^{\circ} 10^{\prime} \mathrm{N}, 128^{\circ} 05^{\prime} \mathrm{E}\right)$, Korea.

\section{Temperature requirement for embryos growth and radicles emergence}

Before laboratory experiments, seeds were disinfected in $70 \%$ ethanol for $2 \mathrm{~min}, 4 \% \mathrm{NaOCl}$ for $15 \mathrm{~min}$, and then rinsed with sterilized water three times. After disinfection, 10 seeds were placed in a plastic Petri dish $(9 \mathrm{~cm} \times 3$ $\mathrm{cm}$ ) each filled with $40-50 \mathrm{~mL}$ of $0.9 \%$ agar and $600 \mathrm{mg} \cdot \mathrm{L}^{-1}$ germicide (Bencide LX 150, Wonyang, Korea). The plastic Petri dishes were sealed with parafilm to control contamination and maintain constant hydration in seeds during the experiments. On $11^{\text {th }}$ of May 2010, three replicates of 20 seeds each were placed in temperature-controlled incubators in the dark at three constant temperatures $\left(10,15\right.$, and $\left.20^{\circ} \mathrm{C}\right)$ or a high temperature of $30^{\circ} \mathrm{C}$ for 2,4 or 8 weeks followed by $15^{\circ} \mathrm{C}$ for 26 weeks. Seeds were monitored at 5 day intervals for 26 weeks, and those with a radicle of more than $2 \mathrm{~mm}$ in length were recorded as an emerged radicle.

\section{Effect of $\mathrm{GA}_{3}$ on radicles emergence of seeds}

Seeds were imbibed in distilled water or $\mathrm{GA}_{3}$ solutions of 200 or $500 \mathrm{mg} \cdot \mathrm{L}^{-1}$ for $24 \mathrm{~h}$ at room temperature. After pretreatment of $\mathrm{GA}_{3}$, seeds were surface-sterilized by the method described above. On 11 May 2010, three replicates of 20 seeds each were placed in plastic Petri dishes on the same solidified agar described above and incubated at 10,15 , and $20^{\circ} \mathrm{C}$, respectively. Observations during 26 weeks of incubation were the same as those described above.

Intact seeds of $H$. asiatica collected in May 2011 were imbibed in distilled water (control) or $\mathrm{GA}_{3}$ solutions of 400 or $800 \mathrm{mg} \cdot \mathrm{L}^{-1}$ for $24 \mathrm{~h}$ at room temperature. After pretreatment, 100 seeds per treatment were placed in $15-\mathrm{mL}$ plastic tubes that contained moistened sand mixed with $600 \mathrm{mg} \cdot \mathrm{L}^{-1}$ germicide (Bencide LX 150, Wonyang, Korea) and these tubes were incubated at $15^{\circ} \mathrm{C}$ in dark incubators. For investigation, 10 seeds were picked out of the incubator at 2 week intervals for 22 weeks. Morphological changes in embryo and the extent of seeds staining were observed under a dissecting microscope (SMZ-168 series, Motic Incorporation Ltd., Hong kong) using tetrazolium chloride staining (Nomizu et al., 2004). Morphological changes in embryo were identified according to developmental stages shown in the seeds of H. nobilis Schreber var. japonica Nakai as follows: inviable seeds (IVS), globular embryo (GE), heart-shaped embryo (HSE), torpedo-shaped embryo (TSE), cotyledon-shaped embryo (CSE), and radicle emergence (RE).

\section{Observation of embryos growth and viability of seeds}

At the end of laboratory experiments and during 26 weeks of incubation, seeds viability and embryos growth were assessed using tetrazolium chloride staining and observation on morphology of embryos. Assessment for seeds viability and embryos growth were divided into five categories based on the observation by tetrazolium chloride staining (Brown, 1996) as follows: level 4, normal embryo growth and normal staining (Fig. 1B, C and D); level 3, normal embryo growth and partial staining (Fig. 1D); level 2, normal embryo growth and poor staining (Fig. 1E and F); level 1, normal embryo growth and no staining (Fig. 1G); level 0, poor embryo growth and no staining (Fig. $1 \mathrm{H}$ and I). Seeds with elongated embryos were regarded as seeds with normal embryo growth, but unstained or rotten seeds as inviable ones.

\section{Data analysis}

Percentage of radicle emergence, mean radicle emergence time (MRET) or coefficient of radicle emergence rate (CRER) were used as a parameter for radicle emergence. Percentage of radicle emergence is the proportion of radicle-emerged 
seeds to the total number of seeds after 21 weeks at $15^{\circ} \mathrm{C}$. The MRET was calculated as

$$
\operatorname{MRET}=(\Sigma \mathrm{n} \times \mathrm{d}) /(\Sigma \mathrm{n})
$$

where $\mathrm{n}$ is number of seeds completed radicle emergence, and $\mathrm{d}$ is the time (days) counting from the date of starting the radicle emergence test (day 0). CRER is the reciprocal of MRET, and expressed as percentage (Mamo et al., 2006). Viability, embryo growth and radicle emergence of seeds were analyzed by two-way ANOVA using the univariate

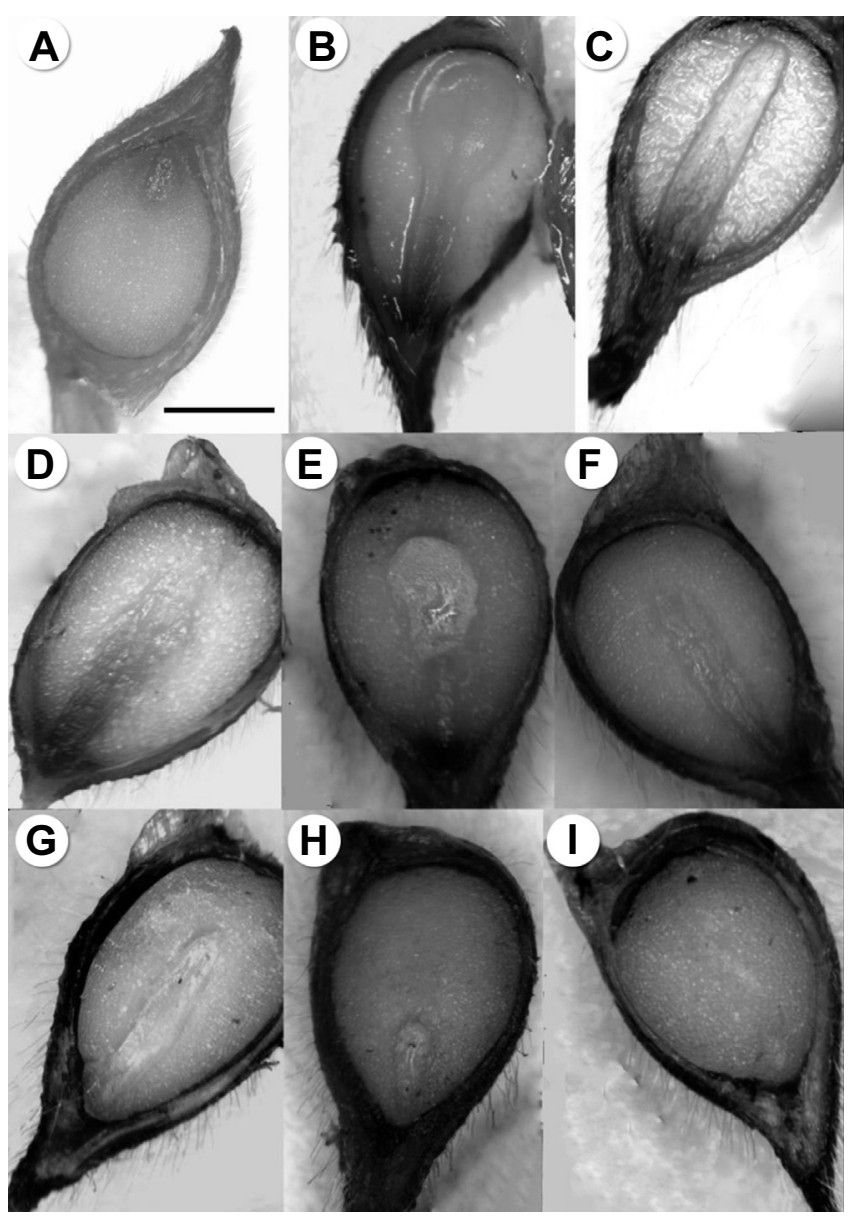

Fig. 1. Morphological changes and staining of embryo in $H$. asiatica seeds incubated at different temperatures $(10,15$, 20 , and $30 \rightarrow 15^{\circ} \mathrm{C}$ ). Seeds were observed in late November, 2010 by tetrazolium chloride staining test. A: seed collected at dispersal from the plant; B and C: level 4, normal embryo growth and normal staining; D: level 3, normal embryo growth and partial staining; E and F: level 2, normal embryo growth and poor staining; G: level 1, normal embryo growth and no staining; $\mathrm{H}$ and $\mathrm{I}$ : level 0 , poor embryo growth and no staining. Seeds corresponding to $\mathrm{G}, \mathrm{H}$ and I with rotten seeds were classified into inviable seeds. Bar $=1.5 \mathrm{~mm}$. process of general linear model (GLM) for two factors, $\mathrm{GA}_{3}$ and temperatures with three levels respectively or $\mathrm{GA}_{3}$ with three levels and various incubation time. A one-way ANOVA was employed to examine the effect of temperature or $\mathrm{GA}_{3}$ treatment on radicle emergence, MRET, CRER, embryo growth, viability, and inviable seeds. Multiple comparisons of means were made with Duncan's test at 0.05 probability level (SPSS 7.0, USA). Relationships among variables were determined using simple linear and nonlinear regression tests with $95 \%$ confidence interval.

\section{Results}

Temperature requirements for embryo growth and radicle emergence

Radicle emergence of $H$. asiatica was less than $10 \%$ in seeds incubated at constant $10^{\circ} \mathrm{C}$ or $20^{\circ} \mathrm{C}$ for 26 weeks (Fig. 2A). Seeds exposed to constant $15^{\circ} \mathrm{C}$ showed more than $40 \%$ of radicle emergence, but that was decreased to $10 \%$ when seeds were warm stratified at $30^{\circ} \mathrm{C}$ for 4 weeks then incubated at $15^{\circ} \mathrm{C}$. Both of seed viability and embryo growth were highest at $15^{\circ} \mathrm{C}(70 \%$ and $78 \%$ respectively), but they were lowest (30\% and $16 \%$ respectively) in seeds incubated at $15^{\circ} \mathrm{C}$ following warm stratification at $30^{\circ} \mathrm{C}$. Embryos were elongated inside $78 \%$ of the seeds incubated at both 10 and $15^{\circ} \mathrm{C}$, but $50 \%$ of seeds at $20^{\circ} \mathrm{C}$ showed elongated embryos and the percentage was less $(16 \%)$ in seeds incubated at $15^{\circ} \mathrm{C}$ following warm stratification at $30^{\circ} \mathrm{C}$ for 4 weeks. There were significant differences among these treatments $(p<0.05)$.

With an exemption of a specific response at $15^{\circ} \mathrm{C}$, there were linear relationships between exposure to temperature and seed viability, embryo growth or radicle emergence (Fig. 2B). Seed viability and embryo growth had an inverse relationship with increasing temperatures $\left(\mathrm{r}^{2}=0.98\right)$. $H$. asiatica seeds exposed to $\geq 20^{\circ} \mathrm{C}$ had a deleterious effect on embryo elongation. Embryo growth with a higher slope $(-3.1)$ was more seriously affected by temperature than seed viability (-1.1). However, exposure to $15^{\circ} \mathrm{C}$ significantly affected radicle emergence, while there was no significant difference at 10,20 or $30^{\circ} \mathrm{C}$ where only $6-8 \%$ seeds had emerged radicles. Embryo elongation and radicle emergence occurred in seed viability-dependent manner (Fig. 2C). However, the dependent relationships were not linear $\left(\mathrm{r}^{2}=\right.$ 0.72-0.75 in linear regression test). Seed viability corresponding to $50 \%$ of maximum embryo growth and radicle emergence were approximately $35 \%$ and $62 \%$, respectively. Also, there was an inverse relationship between embryo elongation and inviable seeds (Fig. 2D). 

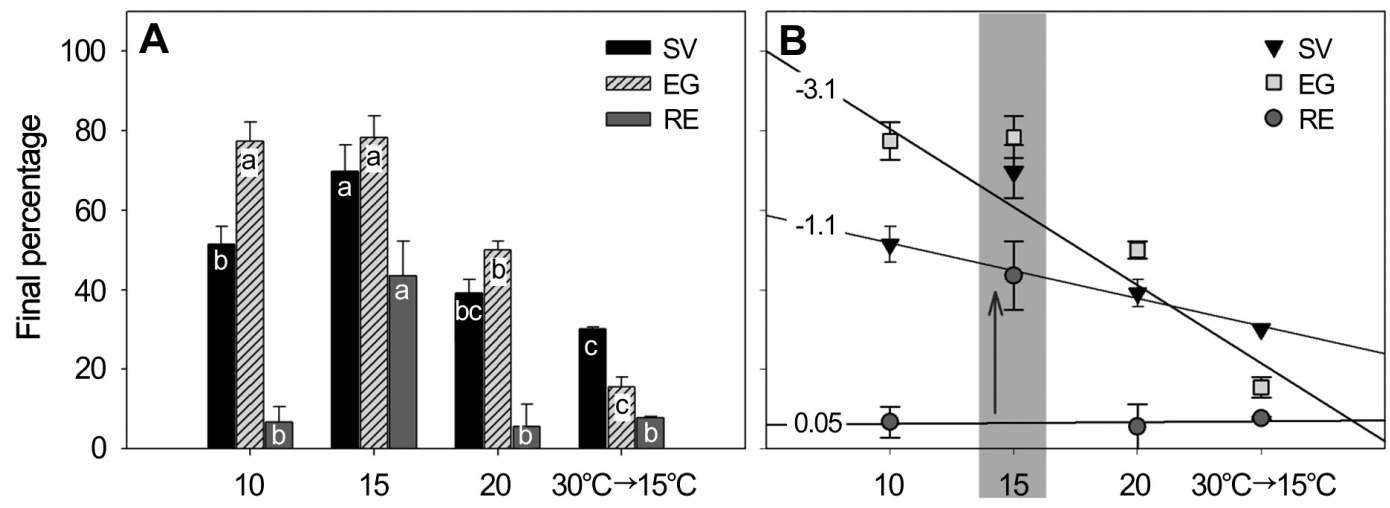

Exposure temperature $\left({ }^{\circ} \mathrm{C}\right)$

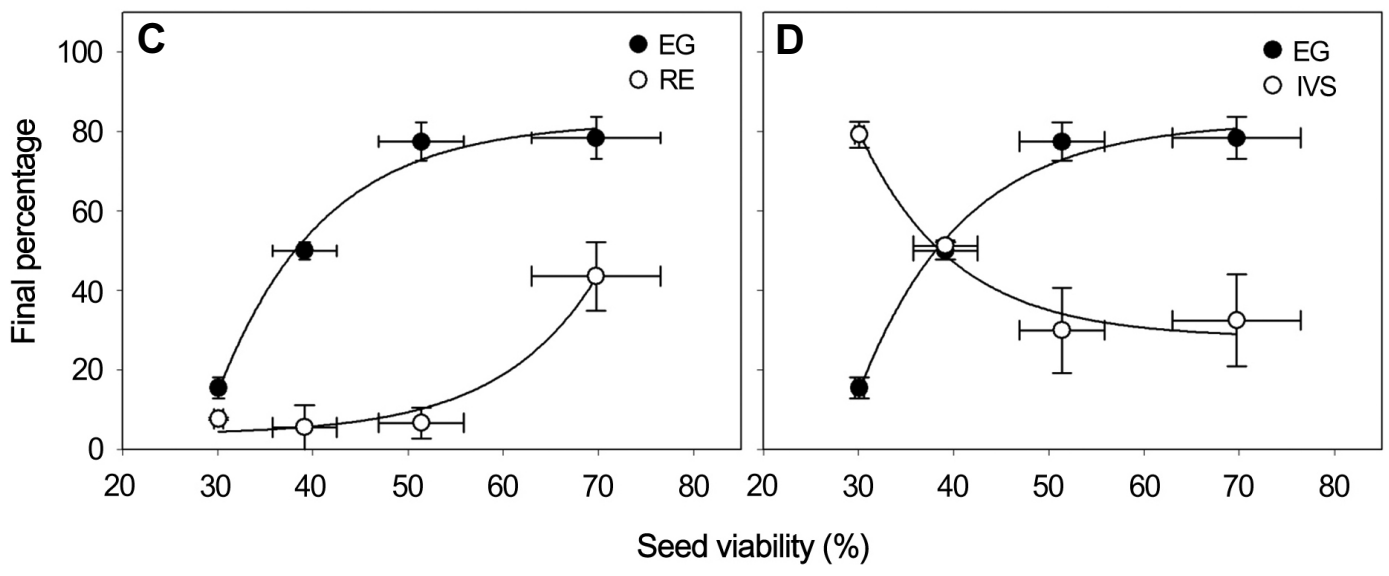

Fig. 2. A: Seed viability (SV), embryo growth (EG) and radicle emergence (RE) determined by TZ staining after 26 weeks at various temperatures $\left(10,15,20^{\circ} \mathrm{C}\right.$, or $15^{\circ} \mathrm{C}$ after 4 weeks at $\left.30^{\circ} \mathrm{C}\right)$. Different letters in each bar show significant difference between SV, EG, and RE ( $p<0.05$ by DMRT); B: Relationship between incubation temperature and seed viability, embryo growth or radicle emergence. Each value presents slopes for linear regression tests excluding data at $15^{\circ} \mathrm{C} ; \mathrm{C}$ and $\mathrm{D}$ : nonlinear relationship between seed viability and embryo growth (EG), inviable seeds (IVS) or radicle emergence (RE, $\mathrm{r}^{2}>0.98, p$ $<0.001)$. Error bars represent \pm SE.

\section{Effect of $\mathrm{GA}_{3}$ on radicle emergence}

When seeds imbibed in 0 (distilled water, control), 200 or $500 \mathrm{mg} \cdot \mathrm{L}^{-1} \mathrm{GA}_{3}$ solution were incubated at $15^{\circ} \mathrm{C}$ for 26 weeks, radicle protrusion occurred significantly earlier in seeds treated with $\mathrm{GA}_{3}$ than the control $(p<0.05$, Fig. $3 \mathrm{~A})$. In seeds imbibed in 200 or $500 \mathrm{mg} \cdot \mathrm{L}^{-1} \mathrm{GA}_{3}$ solution, radicle emergence increased to approximately $10 \%$ after 12 weeks of incubation at $15^{\circ} \mathrm{C}$ and rapidly reached $33 \%$ within 16 weeks. This resulted in a significant difference in the marginal mean of radicle emergence for each time throughout the experiment between $\mathrm{GA}_{3}$ and water-imbibed seeds $(p<0.05$, Fig. 3A). MRET was decreased by $24 \mathrm{~h}$ of seeds soaking in $500 \mathrm{mg} \cdot \mathrm{L}^{-1} \mathrm{GA}_{3}$ and CRER was increased significantly from 5.4 to $6.4 \%$ per week $(p<0.05$, Table 1). Thus, $\mathrm{GA}_{3}$ stimulated the speed of radicle emergence. However, seeds imbibed in distilled water and $\mathrm{GA}_{3}$ solutions reached 38 and $42 \%$ radicle emergence after 22 weeks of incubation at $15^{\circ} \mathrm{C}$, respectively (Table 1). These final percentages of radicle emergence were not significantly different $(p>0.05)$.

In seeds incubated at 10 or $20^{\circ} \mathrm{C}$, final percentages of radicle emergence was very low ( $<10 \%)$ and not significantly affected by any $\mathrm{GA}_{3}$ concentration ( $p>0.05$, Fig. 3B). However, the embryo growth inhibited at $20^{\circ} \mathrm{C}$ was significantly stimulated by imbibition in $500 \mathrm{mg} \cdot \mathrm{L}^{-1} \mathrm{GA}_{3}$ up to a level of embryo growth more than at 10 or $15^{\circ} \mathrm{C}$ (Fig. 3C).

In seeds imbibed in $\mathrm{GA}_{3}$ solution ( 400 or $800 \mathrm{mg} \cdot \mathrm{L}^{-1}$ ) for $24 \mathrm{~h}$, morphological changes of embryos in moist sand during 22 weeks incubation at $15^{\circ} \mathrm{C}$ are represented in Fig. 4. Radicles did not emerge from seeds imbibed in distilled water (control) (Fig. 4A), unlike those incubated on just agar at $15^{\circ} \mathrm{C}$ (Fig. 3A). Globular embryos developed 

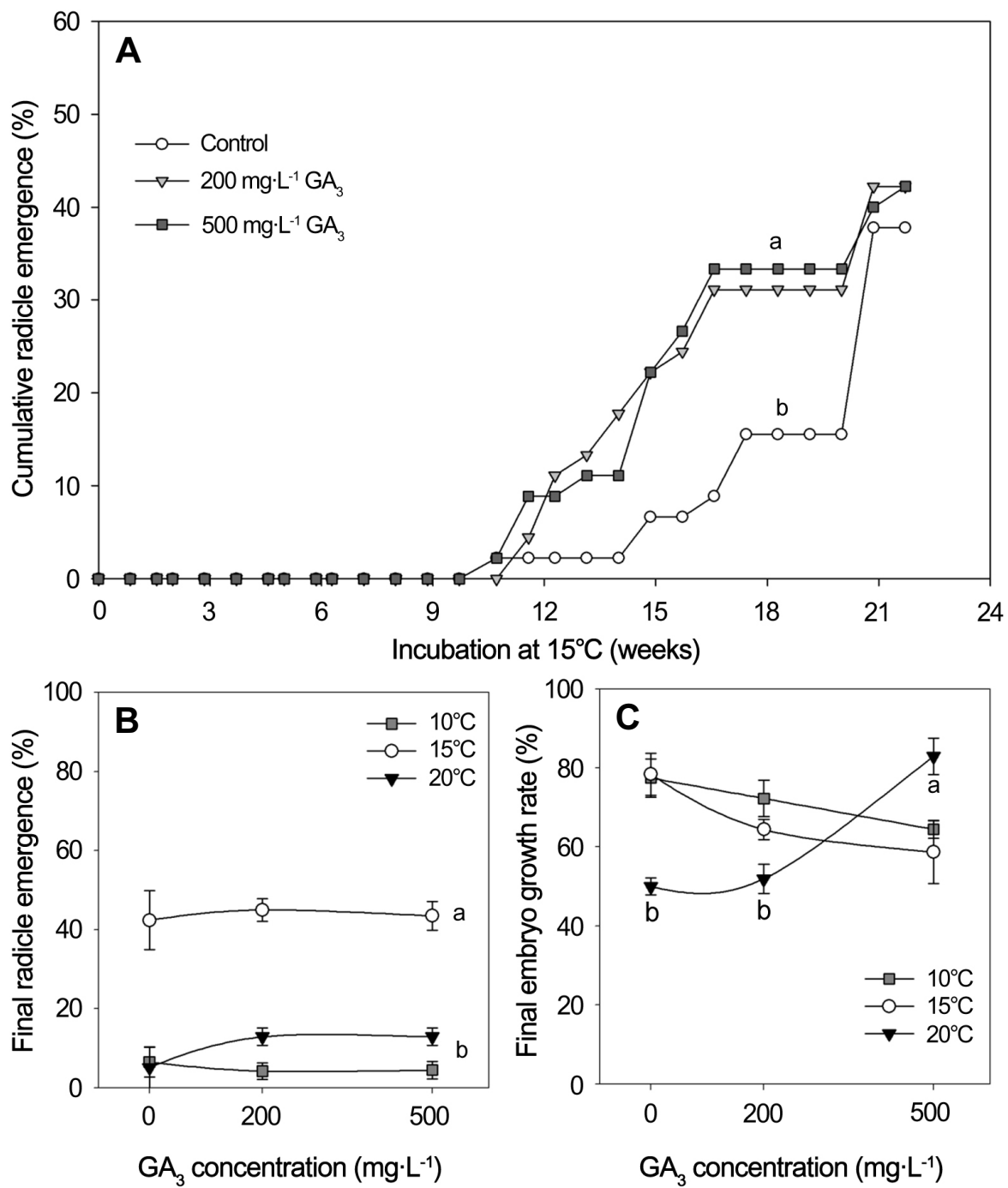

Fig. 3. Cumulative percentage of radicle emergence $(A)$ and final radicle emergence $(B)$ or embryo growth $(C)$ vs. GA 3 concentrations during 22 weeks incubation at $15^{\circ} \mathrm{C}$ after imbibition in 0,200 or $500 \mathrm{mg} \cdot \mathrm{L}^{-1}$ of $\mathrm{GA}_{3}$ solutions in $H$. asiatica seeds. Different letters are significantly different. Data in A and B were analyzed using the general linear model (GLM) univariate procedure to perform a two-way ANOVA to test an interaction between the two factors (A: imbibition time and GA 3 concentration, $\mathrm{B}: \mathrm{GA}_{3}$ concentration and temperature). The estimated marginal means for radicle emergence in $\mathrm{A}$ and $\mathrm{B}$ displayed two significantly different groups $(p<0.05)$. One-way ANOVA, followed by Duncan's multiple comparison test, was performed to test the effect of $\mathrm{GA}_{3}$ on embryo growth at $20^{\circ} \mathrm{C}(\mathrm{C}, p<0.05)$. Error bars represent $\pm \mathrm{SE}$.

into the heart-shaped or torpedo-shaped embryos, but cotyledon-shaped embryos were not observed even after 22 weeks of incubation (Fig. 4A). In contrast, imbibition in $\mathrm{GA}_{3}$ solutions stimulated embryo growth and radicle emergence. In seeds imbibed in 400 or $800 \mathrm{mg} \cdot \mathrm{L}^{-1} \mathrm{GA}_{3}$ solution, radicles began to emerge between 8 and 10 weeks after incubation at $15^{\circ} \mathrm{C}$ (Fig. $4 \mathrm{~B}$ and $\mathrm{C}$ ) and continued to emerge by $20-60 \%$ until 22 weeks of incubation. Cotyledonshaped embryos and emerged radicles appeared more frequently in seeds treated with $800 \mathrm{mg} \cdot \mathrm{L}^{-1}$ than $400 \mathrm{mg} \cdot \mathrm{L}^{-1}$ $\mathrm{GA}_{3}$ solutions, but globular embryos appeared less frequently in seeds treated with both $\mathrm{GA}_{3}$ solutions than in the control. Heart-shaped embryos were not observed in seeds treated with both $\mathrm{GA}_{3}$ solutions, but torpedo-shaped and cotyledonshaped embryos increased. Imbibition in $800 \mathrm{mg} \cdot \mathrm{L}^{-1} \mathrm{GA}_{3}$ was more effective in stimulating embryo growth and radicle emergence than $400 \mathrm{mg} \cdot \mathrm{L}^{-1} \mathrm{GA}_{3}$ (Fig. 4C). Seeds imbibed in distilled water and $400 \mathrm{mg} \cdot \mathrm{L}^{-1} \mathrm{GA}_{3}$ lost their viability 
Table 1. Radicle emergence characteristics of $H$. asiatica seeds incubated at $15^{\circ} \mathrm{C}$ after imbibition in $\mathrm{GA}_{3}$ solutions for 24 h.

\begin{tabular}{|c|c|c|c|c|}
\hline Treatment & & $\begin{array}{c}\text { Radicle emergence }{ }^{\mathrm{z}} \\
(\%)\end{array}$ & $\begin{array}{l}\text { MRET }^{\mathrm{y}} \\
\text { (weeks) }\end{array}$ & $\begin{array}{c}\text { CRER }^{\mathrm{x}} \\
(\text { No./week } \times 100)\end{array}$ \\
\hline \multirow{2}{*}{$\begin{array}{l}\mathrm{GA}_{3} \text { concentration } \\
\left(\mathrm{mg} \cdot \mathrm{L}^{-1}\right)\end{array}$} & 0 & $37.8 \mathrm{a}$ & $18.4 \mathrm{a}$ & $5.39 \mathrm{~b}$ \\
\hline & 500 & $42.2 \mathrm{a}$ & $15.5 \mathrm{~b}$ & $6.44 \mathrm{a}$ \\
\hline
\end{tabular}

Mean values calculated from seeds at $15^{\circ} \mathrm{C}$ after pre-soaking treatment during the period of mid-May to mid-October, 2010 ; means followed by the same letter within concentration levels of $\mathrm{GA}_{3}$ are not significantly different at the $p<0.05$ level (Duncan's multiple comparison test).

${ }^{z}$ Percentage of radicles protruded from total seeds sown in agar.

${ }^{\mathrm{y}} \mathrm{MRET}=\left(\sum \mathrm{n} \times \mathrm{d}\right) /\left(\sum \mathrm{n}\right)$, where $\mathrm{n}$ is number of seeds completing radicle emergence on day $\mathrm{d}$, and $\mathrm{d}$ is the time counting in days from the day starting incubation at $15^{\circ} \mathrm{C}$.

${ }^{\mathrm{x}}$ The reciprocal of MRET expressed as percentage.
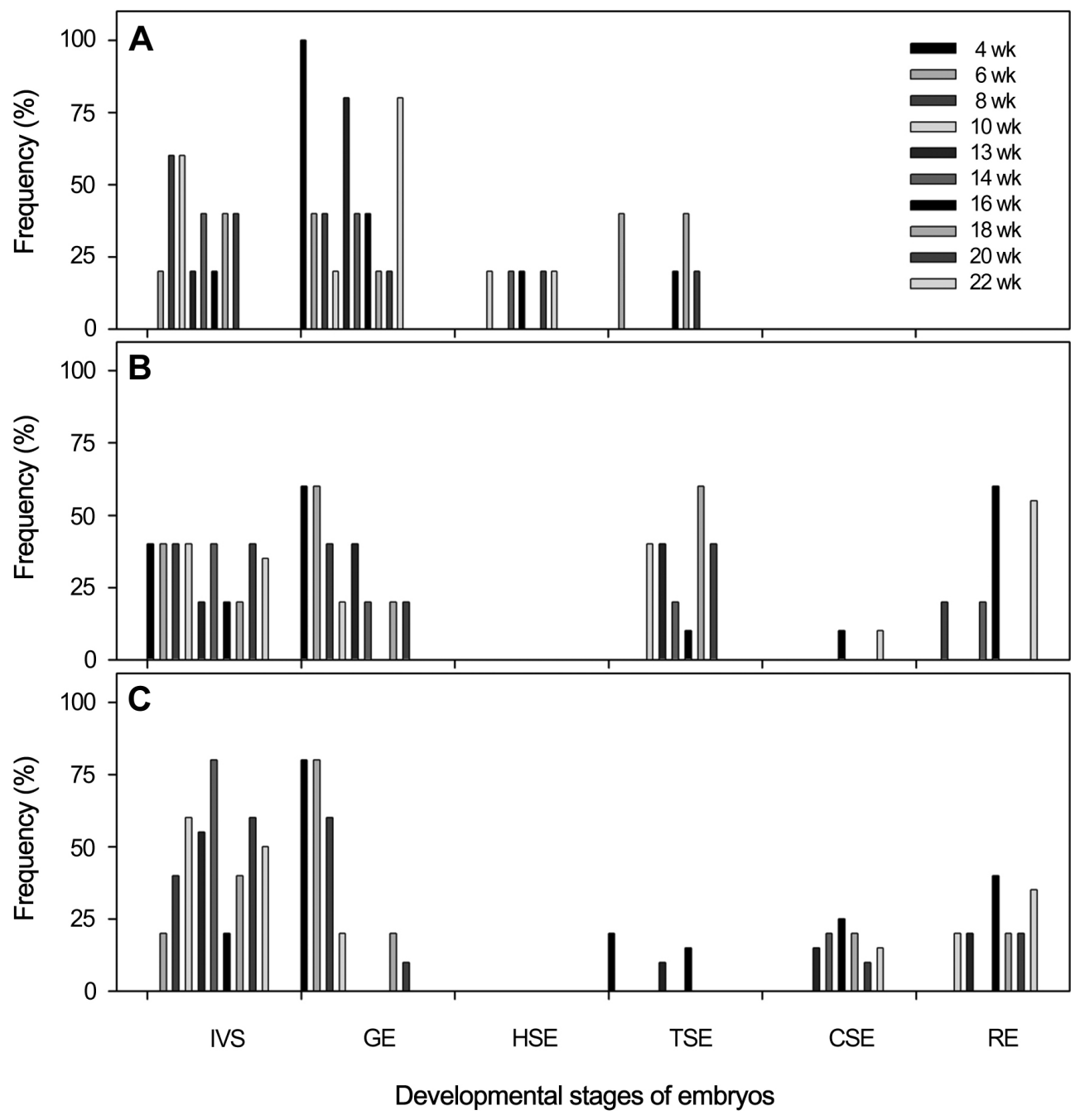

Fig. 4. Frequency distribution of embryo developmental stage and radicle emergence of $H$. asiatica seeds imbibed in 0 (distilled water, A), 400 (B), 800 (C) $\mathrm{mg} \cdot \mathrm{L}^{-1} \mathrm{GA}_{3}$ for $24 \mathrm{~h}$ followed by incubation at $15^{\circ} \mathrm{C}$ in darkness. Each vertical bar indicates percentage of developmental stages of embryos in seeds sampled at each time $(\mathrm{n}=15)$ during 22 weeks. Developmental stages of seeds were abbreviated as follows: inviable seeds, IVS; globular embryo, GE; heart-shaped embryo, HSE; torpedo-shaped embryo, TSE; cotyledon-shaped embryo, CSE; radicle emergence, RE. 
by 30 and 34\%, respectively throughout the experiment. However, inviable seeds increased to $44 \%$ when imbibed in $800 \mathrm{mg} \cdot \mathrm{L}^{-1} \quad \mathrm{GA}_{3}$.

\section{Interaction between incubation temperature and $\mathrm{GA}_{3}$ concentration}

Two-way ANOVA analysis showed significant effects of temperatures between 10 and $20^{\circ} \mathrm{C}$ on radicle emergence, embryo growth, seed viability, and incidence of inviable seeds of $H$. asiatica after 26 week of incubation ( $p \leq 0.05$ ), but not for $\mathrm{GA}_{3}$ concentration $(p>0.05$ ) (Table 2). However, the interaction between incubation temperature and $\mathrm{GA}_{3}$ concentration on embryo growth were significant $(p<0.001)$ (Table 2). Embryo growth of seeds imbibed with $500 \mathrm{mg} \cdot \mathrm{L}^{-1}$ $\mathrm{GA}_{3}$ was significantly greater than in seeds imbibed in distilled water or $200 \mathrm{mg} \cdot \mathrm{L}^{-1} \mathrm{GA}_{3}$ at $20^{\circ} \mathrm{C}$, but not for seeds incubated at 10 and $15^{\circ} \mathrm{C}$ (Fig. 3C).

\section{Discussion}

Seeds of $H$. asiatica have an underdeveloped embryo when dispersed from a parent plant (Fig. 1A), just like other Hepatica spp. including H. Americana (Martin, 1946), H. acutiloba (Baskin and Baskin, 1985) and H. nobilis Schreber
(Engell, 1995; Nomizu et al., 2004). Stratification at $30^{\circ} \mathrm{C}$ for 2-8 weeks before incubating at $15^{\circ} \mathrm{C}$ decreased seed viability, led to inhibition of embryo growth, and resulted in very low radicle emergence (Fig. 2A). A temperature of $30^{\circ} \mathrm{C}$ might be too high to express a stratification effect on $H$. asiatica, possibly due to much lower soil temperature during May to July. In a previous study on $H$. nobilis Schreber var. japonica, incubation at $25^{\circ} \mathrm{C}$ did not promote embryo elongation either (Nomizu et al., 2004). Even a short period of warm stratification at $30^{\circ} \mathrm{C}$ ( 2 weeks) showed a deleterious effect on radicle emergence at $15^{\circ} \mathrm{C}$, but warm stratification at medium temperature of $20-25^{\circ} \mathrm{C}$ might help expedite embryo growth and radicle emergence at $15^{\circ} \mathrm{C}$.

In previous studies on seeds of Eranthis hiemalis (Ranunculaceae), embryos started rapid development when transferred to low temperatures after ripening at $20-25^{\circ} \mathrm{C}$ for 3 weeks (Frost-Christensen, 1974). In natural habitats of $H$. asiatica, monthly mean summer temperatures were recorded between 18 and $24^{\circ} \mathrm{C}$, and during autumn when radicle emergence occurred were around $10-15^{\circ} \mathrm{C}$ (Lim and Sang, 1990). That is consistent with the optimum temperature for radicle emergence of $H$. asiatica seeds found in the present experiment where radicles emergence reached $38 \%$ only at $15^{\circ} \mathrm{C}$ incubation. Radicle emergence in seeds of $H$. nobilis also

Table 2. Two-way ANOVA to test the effect of incubation temperature $\left(10,15\right.$, and $\left.20^{\circ} \mathrm{C}\right)$ and $\mathrm{GA}_{3}$ concentrations $(0,200$, and $500 \mathrm{mg} \cdot \mathrm{L}^{-1}$ ) on radicle emergence, embryo growth, seed viability, and incidence of inviable seeds of $\mathrm{H}$. asiatica seeds at the end of the experiment

\begin{tabular}{lcccc}
\hline Response/source & d.f. & Mean square & F & $p$-value \\
\hline a. Radicle emergence & & & & \\
Temperature & 2 & 8389.3 & 62.2 & 0.00 \\
$\mathrm{GA}_{3}$ concentration & 2 & 0118.9 & 0.88 & 0.43 \\
Temperature $\times \mathrm{GA}_{3}$ concentration & 4 & 93.7 & 0.69 & 0.61 \\
b. Embryo growth & & & \\
Temperature & 2 & 0215.8 & 3.47 & 0.05 \\
$\mathrm{GA}_{3}$ concentration & 2 & 0100.7 & 1.62 & 0.23 \\
Temperature $\times \mathrm{GA}_{3}$ concentration & 4 & 0681.5 & 10.96 & 0.00 \\
c. Seed viability & & & & 0.02 \\
Temperature & 2 & 0735.6 & 5.17 & 0.77 \\
GA concentration & 2 & 0037.3 & 0.26 & 0.28 \\
Temperature $\times \mathrm{GA}_{3}$ concentration & 4 & 0193.9 & 1.36 & 0.03 \\
d. Incidence of inviable seeds & & & & 0.55 \\
Temperature & 2 & 1105.1 & 4.08 & 0.69 \\
$\mathrm{GA}_{3}$ concentration & 2 & 0164.8 & 0.61 & 0.57 \\
Temperature $\times \mathrm{GA}_{3}$ concentration & 4 & 0155.1 & & \\
\hline
\end{tabular}


occurred at this temperature (Nomizu et al., 2004). As shown in seeds of many Ranunculaceae plants (Atwater, 1980; Frost-Christensen, 1974; Nomizu et al., 2004), embryo elongation of $H$. asiatica seeds was rapidly completed between 10 and $15^{\circ} \mathrm{C}$. The present study also showed that embryo growth was more susceptible to temperature (Fig. 2B) and elongation was significantly inhibited when the temperature increased above $20^{\circ} \mathrm{C}$ (Fig. $2 \mathrm{~A}$ and $\mathrm{B}$ ). The highest dependence of embryo growth on temperature (Fig. 2B) could have relevance to previous reports where temperature ranges suitable for embryo development were found to vary for each developmental embryo stage (Atwater, 1980; Frost-Christensen, 1974; Nomizu et al., 2004).

In the present study, $15^{\circ} \mathrm{C}$ was much more effective than other temperature conditions $\left(10,20\right.$ and $\left.30 \rightarrow 15^{\circ} \mathrm{C}\right)$ in breaking dormancy of $H$. asiatica seeds with a significant positive effect on seed viability. Given the inverse relationship between embryo growth and incidence of inviable seeds (Fig. 2D), it seems likely that embryonic cell death occurs as a result of retarded embryo growth. Factors inhibiting embryo development may cause cell death of embryo. Embryo growth and radicle emergence were affected by seed viability (Fig. 2C). Seed viability corresponded to $50 \%$ of maximum radicle emergence was higher than that for $50 \%$ of maximum embryo growth. This might be caused by a higher turgor pressure to puncture the endocarp during radicle extension than that during embryo elongation considering that extension of embryo or radicle is a turgor-driven process (Bewley, 1997).

H. asiatica seeds, maintained at $15^{\circ} \mathrm{C}$, developed into cotyledon-shaped embryo with subsequent radicle emergence, whereas seeds held at $10^{\circ} \mathrm{C}$ elongated as much as at $15^{\circ} \mathrm{C}$, but no emergence of radicle was seen. $\mathrm{GA}_{3}$ pretreatment caused an increase in radicle emergence, but not in the final percentage of radicle emergence at $15^{\circ} \mathrm{C}$. Also, addition of $\mathrm{GA}_{3}$ hardly stimulated radicle emergence at 10 or $20^{\circ} \mathrm{C}$ (<13\%) (Fig. 4B), but remarkably promoted embryo growth at $20^{\circ} \mathrm{C}$ (Fig. 3C). These results indicate that the role of $\mathrm{GA}_{3}$ in $H$. asiatica seeds is related to embryo growth, but not to radicle emergence.

Radicle emerged optimally only at a specific temperature of $15^{\circ} \mathrm{C}$, which indicates that temperature plays an important role in regulating radicle emergence. However, radicles did not emerge from the water-imbibed seeds incubated in moist sand even at the optimum temperature $\left(15^{\circ} \mathrm{C}\right)$ and embryos growth was retarded (Fig. 4A) unlike those on plain agar plates. Meanwhile, in non-imbibed seeds, radicles emerged from the seeds in moist sand at $15^{\circ} \mathrm{C}$ although radicle emergence occurred infrequently with little population (20\%, data not shown). Such a difference between solidified agar and moist sand could be explained by a previous report where it was found that the highest germination (42\%) of fresh seeds of Rosa bractita was obtained when seeds were sown in sphagnum moss, while the lowest percentage $(1.8 \%)$ was obtained when seeds were sown on filter paper (Anderson and Byrne, 2007). Seeds in moist sand might also be affected by less available oxygen due to a difference in air contact and empty volume of container (approximately 7 and $100 \mathrm{~mL}$, respectively). Like seeds of $H$. asiatica in moist sand, germination of rose seeds was also affected by water imbibition, which was decreased by $22 \%$ and $16 \%$ when seeds were incubated after leaching in sphagnum moss and agar, respectively. The inhibitory effect of water imbibition on radicle emergence could be due to a rapid leakage of solutes required for radicle emergence as mentioned in an earlier study (Larson, 1968).

Present and previous reports imply that incubation medium and water imbibition of seeds are important factors in radicle emergence or germination of seeds. Water-imbibed seeds that did not have emerged radicles in moist sand dramatically responded to $\mathrm{GA}_{3}$, which stimulated embryo elongation, and promoted radicle emergence up to maximal $66 \%$ at the concentration of $400 \mathrm{mg} \cdot \mathrm{L}^{-1} \mathrm{GA}_{3}$ solution. However, increased $\mathrm{GA}_{3}$ concentration $\left(800 \mathrm{mg} \cdot \mathrm{L}^{-1}\right)$ showed a tendency to increase inviable seeds despite its stimulation of radicle emergence. Increased inviable seeds caused by $\mathrm{GA}_{3}$ were observed in coffee seeds (da Silva et al., 2005).

There are many reports on the stimulatory effect of gibberellic acids during seed germination (Bewley, 1997; Karssen et al., 1989). Although embryo growth of $H$. asiatica seeds was completed at $10^{\circ} \mathrm{C}$ or by $\mathrm{GA}_{3}$ pretreatment at $20^{\circ} \mathrm{C}$, the elongated embryo was not allowed to have an emerged radicle at these temperatures. Thus, it can be concluded that exogenous $\mathrm{GA}_{3}$ promotes embryo elongation, but not radicle emergence of $H$. asiatica seeds. $\mathrm{GA}_{3}$ is thought to speed up radicle emergence of seeds at $15^{\circ} \mathrm{C}$ by promoting embryo growth, which also can be explained by the result of embryo elongation stimulated by $\mathrm{GA}_{3}$ in moist sand (Fig. 4).

The most significant finding of this study is that $H$. asiatica seeds have two separate parts of dormancy for embryo and radicle. The break of first part of dormancy lead to a fully developed embryo, which occured equally well at 10 and $15^{\circ} \mathrm{C}$ and the dormancy at $20^{\circ} \mathrm{C}$ was overcome by pretreatment with $\mathrm{GA}_{3}$. However, the break of second part of dormancy lead to radicle emergence more effectively only at $15^{\circ} \mathrm{C}$ and this part of dormancy cannot be overcome 
by pretreatment with $\mathrm{GA}_{3}$ at lower or higher temperatures $\left(10\right.$ and $\left.20^{\circ} \mathrm{C}\right)$. These results indicat that $H$. asiatica seeds have morphophysiological dormancy.

\section{Literature Cited}

Anderson, N. and D.H. Byrne. 2007. Methods for Rosa germination. Acta Hortic. 751:503-507.

Atwater, B.R. 1980. Germination, dormancy and morphology of the seeds of herbaceous ornamental plants. Seed Sci. Technol. 8:523-573.

Baskin, J.M. and C.C. Baskin. 1985. Epicotyl dormancy in seeds of Cimicifuga racemosa and Hepatica acutiloba. Bull. Torrey Bot. Club 112:253-257.

Bewley, J.D. 1997. Seed germination and dormancy. Plant Cell 9:1055-1066.

Brown, L.B. 1996. Applied principles of horticultural science. Butterworth-Heinemann, Oxford.

Chi, H.J. and S.Y. Lee. 1981. Phytochemical survey of higher plants in Korea. Kor. J. Pharmacogn. 12:75-76.

Da Silva, E.A., P.E. Toorop, J. Nijsse, J.D. Bewley, and H.W. Hilhorst. 2005. Exogenous gibberellins inhibit coffee (Coffea arabica cv. Rubi) seed germination and cause cell death in the embryo. J. Expt. Bot. 56:1029-1038.

Engell, K. 1995. Embryo morphology of the Ranunculaceae. Plant Systematics and Evol. (Suppl.) 9:207-216.

Frost-Christensen, H. 1974. Embryo development in ripe seeds of Eranthis hiemalis and its relation to gibberellic acid. Physiol. Plant 30:200-205.

Hara, H. 1952. Hepatica nobilis Schreb var. asiatica (Nakai) Hara. J. Fac. Sci. Uni. Tokyo 3:51.

Hara, H. and S. Kurosawa. 1958. Differentiation within Anemone hepatica L. of Japan. J. Jpn. Bot. 331:9-18.

Hong, J.U., 1995. Physiological and ecological study of Hepatica asiatica N. (I) Comm. Dev. Res. 4:1-8.

Karssen, C.M., S. Zagorski, J. Kepczynski, and S.P.C. Groot. 1989.
Key role for endogenous gibberellins in the control of seed germination. Ann. Bot. 63:71-80.

Kim, J.H. and N.S. Lee. 1994. Allozyme variation in Hepatica asiatica and H. insularis. Kor. J. Plant Tax. 24:79-93.

Larson, L.A. 1968. The effect soaking pea seeds with or without seedcoats has on seedling growth. Plant Physiol. 43:255-259.

Lee, C.B. 1982. An illustrated guide to Korean flora. Hyangmunsa, Seoul.

Lee, M.J., K.H. Lee, and K.S. Chae. 2005. Differentiation and development of flower bud in Hepatica asiatica Nakai. Kor. J. Hort. Sci. Technol. 23:451-454.

Lim, J.H. and C.K. Sang. 1990. Growth condition of Hepatica asiatica Nakai in the habitats for the cultivation as floricultural crop. J. Kor. Soc. Hort. Sci. 31:81-89.

Lim, Y.H., M.H. Kim, M.S. Byun, and K.W. Kim. 2007. Effects of $\mathrm{GA}_{3}$ and chilling treatment on growth and flowering in perennial Korean native plants. Flower Res. J. 15:123-129.

Mamo, N., M. Mihretu, M. Fekadu, M. Tigabu, and D. Teketay. 2006. Variation in seed and germination characteristics among Juniperus procera populations in Ethiopia. Forest Ecol. Mgt. 225:320-327.

Martin, A.C. 1946. The comparative internal morphology of seeds. Am. Midl. Nat. 36:513-660.

Nakai, T. 1937. Japanese Hepatica. J. Jpn. Bot.13:227-243.

Nomizu, T., Y. Niimi, and E. Watanabe. 2004. Embryo development and seed germination of Hepatica nobilis Schreber var. japonica as affected by temperature after sowing. Sci. Hortic. 99:345-352.

Song, J.S., Y.D. Chang, H.H. Chung, C.S. Bang, and J.Y. Kim. 2003. Floral initiation and flowering response of potted Hepatica asiatica to low Temperature and $\mathrm{GA}_{3}$. J. Kor. Soc. Hort. Sci. 44:928-930.

Tamura, M. 1993. Ranunculaceae, p. 563-583. In: Kubitzki, K., Rohwer, J.G., Bittrich, V. (Eds.), The families and genera of vascular plants II. Flowering Plants - Dicotyledons. Springer, Berlin. 